\title{
RESPONSE OF COMMERCIAL LAYERS TO HOUSING AT DIFFERENT CAGE DENSITIES AND HEAT STRESS CONDITIONS. 1- PHYSIOLOGICAL INDICATORS AND IMMUNE RESPONSE
}

\author{
H. B. A. Gharib, M. A. El- Menawey, A. A. Attalla and F. K. R. Stino
}

Department of Animal production, Faculty of Agriculture, Cairo University, Giza, Egypt

\section{SUMMARY}

An experiment was conducted to determine the effects of heat stress and different cage densities on blood indices and Immune response. The hypothesis that, commercial layers, caged at lower densities, react less intensely, to heat stress, than would the hens caged at higher densities was also tested. A total of 936, Lohman Selected Leghorn (LSL) hens, fifty eight weeks old, were used in this experiment. These hens were originally housed, at eighteen weeks of age, as follows: 1- The first group (468 hens) was housed in a conventional open-sided house (Heat Stressed). 2The second group (468 hens) was housed in a conventional open-sided house with desert cooling systems (Control). Pullets were placed at 4, 5, 6, 7, 8 and 9 birds per cage in wire cages ( $60 \mathrm{~cm}$ wide by $50 \mathrm{~cm}$ deep and $40 \mathrm{~cm}$ height). At 58 weeks of age, the first group was exposed to high environmental temperatures, ranging from 40$42^{\circ} \mathrm{C}$ and $65-70 \%$ relative humidity (five hours daily for seven consecutive days). After each daily heat exposure, the hens were exposed to the normal ambient temperature of the season $\left(20-26{ }^{\circ} \mathrm{C}\right.$ and $60-65 \%$ relative humidity). The control group was exposed to the ambient temperatures of the season, ranging from $20-26^{\circ} \mathrm{C}$ and $60-65 \%$ relative humidity. Data were collected during the period of heat stress exposure .

Results indicated that rectal temperature and Heterophil: Lymphocyte ratios (H:L ratios) of heat-stressed birds, increased significantly as compared to the control group, at the first and last days of heat stress. However, red blood cell count, packed cell volume, hemoglobin concentration, plasma total protein, globulin and serum potassium levels, of heat stressed birds, decreased significantly as compared to the control ones, when tested at both the first and last day of heat stress. Plasma albumin and serum calcium levels, of heat stressed birds, decreased significantly as compared to the control group, only at the first day of heat stress. Also, heat exposure reduced antibody titers against sheep red blood cell's (SRBC's) on 3, 5 and 7 days post immunization.

No significant detrimental effects, due to heat stress, on serum calcium and potassium levels, were observed, when hens were housed at the lowest cage density (4 hens/cage), at the first day of heat stress. At the last day of heat stress, plasma proteins, serum calcium and potassium levels, and H:L ratio, were also not affected, when hens were housed at the lowest cage density. Antibody titers against SRBC's, were significantly reduced due to heat stress, when hens were housed at 9 per cage, 
on the $3^{\text {rd }}$ day post immunization. On the $5^{\text {th }}$ day post immunization, when 8 or 9 hens were housed per cage, antibody titers against SRBC's also, decreased significantly, due to heat stress.

Under heat stress conditions, hens caged at low densities (4 or 5 birds/cage) had significantly lower rectal temperatures, and higher serum calcium and potassium levels, when compared to hens at higher cage densities. Significantly higher antibody titers against SRBC's and lower H:L ratios were also observed when hens were caged at lower densities. It was concluded that, hens caged at low densities were less affected by heat stress than those at higher cage densities.

Keywords: Laying hens, Heat stress, Cage densities, Physiological indicators, Immune response

\section{INTRODUCTION}

Layers are susceptible to heat stress for several reasons. First, their metabolic heat production is high as a result of the high rate of egg production (Blem, 2000). Second, there is little heat dissipation by convection and radiation, because of the very effective insulation of the body surface by their feathers. Third, the hens lack sweat glands, and their respiratory water evaporation rate is not high enough to maintain normalthermia at high ambient temperatures (Etches et al., 1995 ; Dawson and Whittow, 2000).

Heat stress has adverse effects on chicken's mineral balance, and plasma electrolyte concentrations (Deyhim and Teeter, 1990; Belay and Teeter, 1993), alterations in immune function (Klasing and Benson, 1990 ; Belay and Teeter, 1994) and it impedes with disease resistance (Ferket and Qureshi, 1992).

In general, heat stress leads to decrease total red blood cell's, per unit volume of blood, which in turn decreases hemoglobin concentration and packed cell volume. That is due to the positive relation between red blood cell's, hemoglobin concentration and packed cell volume (Sturkie, 1986).

A rise in body temperature, in response to high environmental temperature, was also reported by Cheng et al. (1990) and Wolfenson et al. (2001).

Evidence suggests that plasma protein levels may indicate the effect of heat stress on chickens (Kutlu and Forber, 1993 ; Berrong and Washburn, 1998). Ahmed et al. (1967) indicated that exposing hens to high ambient temperature leads to a decrease in protein synthesis. Exposure to heat stress significantly decrease serum or plasma calcium and phosphorus concentrations (Usayran et al., 2001). Ait-Boulahsen et al., (1989) reported a decrease in potassium concentration and an increase in sodium concentration due to heat stress.

Excessive environmental temperatures can alter the immune function through reducing antibody production (Brake, 1989 ; Siegel, 1989). Also, in vitro, phagocytic potential of chicken macrophages decreased during heat-stress conditions (Miller and Qureshi, 1991). Donker et al. (1990) demonstrated that heat stress treatment significantly lowered antibody titers against sheep red blood cells (SRBC's) on days $3,5,7$ and 10 after immunization.

The decrease in layer performance, as the cage density increases, could be the results of some physiological stresses. Many physiological variables have been assessed as indicators of high cage density stress. The stress, caused by high cage 
densities, were reported to cause an increase in plasma corticosterone concentrations (Mashaly et al., 1984). This stress also increased the heterophil to lymphocyte ratios (Hester et al., 1996b; Gharib et al., 2005). Decreased red blood cells counts, serum calcium and phosphorus levels, and antibody titers against SRBC's were also reported by Gharib et al., (2005) due to high cage densities.

The objectives of this study were, to test the hypothesis that, commercial layers, caged at low densities, are less affected by heat stress, than the hens caged at higher densities. Also the effects of heat stress and different cage densities on some physiological indicators, and the immune response of layers were studied.

\section{MATERIALS AND METHODS}

The present study was carried out at the Poultry Research Center, Department of Animal Production, Faculty of Agriculture, Cairo University.

A total of 936, Lohman Selected Leghorn (LSL) hens, were used in this experiment. These hens, since eighteen weeks of age, were divided into two groups (468 hens each) as follows: the first group was placed in a conventional open-sided house, (House M). The second group was placed in a conventional open-sided house with desert cooling system (House $\mathrm{CD}$ ). Birds of each group were divided into six subgroups. Birds were placed at $4\left(\mathrm{C}_{4}\right), 5\left(\mathrm{C}_{5}\right), 6\left(\mathrm{C}_{6}\right), 7\left(\mathrm{C}_{7}\right), 8\left(\mathrm{C}_{8}\right)$ and $9\left(\mathrm{C}_{9}\right)$ birds per cage, with two water nipples for each, in wire cages $(60 \mathrm{~cm}$ wide by $50 \mathrm{~cm}$ deep and $40 \mathrm{~cm}$ height). The corresponding floor areas, per bird were 750, 600, 500, 428, 375 and $333 \mathrm{Cm}^{2}$, respectively. The corresponding feeding spaces were $15,12,10$, 8.6, 7.5 and $6.7 \mathrm{Cm}$, per bird, respectively. To mentain the assigned cage densities per group depletion, due to mortality, were replaced on the same day.

The birds, in production, received a commercial layer ration (17\% C.P and 2800 $\mathrm{Kcal} \mathrm{Me} / \mathrm{Kg}$ ) and water ad libitum. Seventeen hours of light were also provided daily.

At 58 weeks of age, the birds in M House were exposed to high environmental temperature (heat stressed), ranging from $40-42^{\circ} \mathrm{C}$ and $65-70 \%$ relative humidity (five hours daily for seven consecutive days). This was achieved by using electric fan heaters. After the five hours of heat stress, the birds were exposed to the normal ambient temperature of the season $\left(20-26^{\circ} \mathrm{C}\right)$ and $60-65 \%$ relative humidity. The CD House group (control) was exposed to normal ambient temperature ranging from $20-26^{\mathrm{O}} \mathrm{C}$ and $60-65 \%$ relative humidity.

\section{Data Collected:}

\section{A) Physiological Indicators:}

Blood samples were collected from 10 hens (from 10 different cages), within cage density, within house, after four hours of exposing the birds to the high temperature, at the first and last days of the heat stress treatment. The blood samples (about 3 $\mathrm{ml} /$ hen) were collected via the brachial vein and it was divided between heparinized and non heparinized test tubes. Plasma and serum were separated by centrifugation at $3200 \mathrm{rpm}$ for 20 minutes and 10 minutes, respectively. Plasma and serum samples were transferred to clean dry vials and kept in a deep freezer at $-20^{\circ} \mathrm{C}$ until used.

\section{A-1) Rectal Temperature:}

At the first and last days of the heat stress period, 20 birds (two birds per cage), within cage density, within house, were used to measure rectal temperature, as an 
indicator of body temperature. Rectal temperature was measured by inserting an electronic thermometer, into the cloacae, to the depth of $1 \mathrm{~cm}$, for one minute.

\section{A-2) Physiological properties}

A-2-a) Total Red Blood Cells (RBC's):

Total RBC's was determined by a haemocytometer (Hartman and Leeseler, 1963).

A-2-b) Packed Cell Volume \% (PCV):

PCV value was determined by the microhematocrit method of Hunsaker (1969).

A-2-c) Hemoglobin Concentration (HbC):

Hemoglobin concentration $(\mathrm{g} / 100 \mathrm{~mL}$ blood $)$ was determined by a hemoglobinometer (Pilaski, 1972).

A-3) Chemical Constituents:

The spectrophotometric technique (Henry, 1974) was used to determine, plasma total protein and albumen; serum calcium, and potassium.

A-4) Heterophil : Lymphocyte Ratio (H:L ratio):

Blood samples were collected from the brachial vein of 10 birds (from 10 different cages), within cage density, whitin group, at the first and last days of heat stress exposure. H:L ratios were determined using the technique of Gross and Siegel (1983). A hundred leucocytes were counted, per slide, then they were differentiated, and the ratio of H:L was calculated.

\section{B) Immune Response}

\section{Antibody Measurement:}

Sheep red blood cells (SRBC'S) were used as test antigens to quantitatively analyze specific antibody responses, as a measure of humoral immunocompetence. Ten hens, (from 10 different cages) within cage density, within house, were injected, at 58 weeks of age, intramuscularly, by $1 \mathrm{ml}$ of $10 \%$ SRBC'S suspension prepared in $0.9 \%$ physiological saline. The heat stressed and control hens were injected one hour after the initiation of heat stress at the first day of heat exposure . On 3, 5 and 7 days post immunization, blood samples were collected to determine the primary antibody responses. Antibody titers were determined using U-shaped micro titration plates with 96 wells (Van der Zijpp and Leenstra, 1980). Antibody titer values were expressed as $\log 2$ of the highest serum dilution giving total agglutination.

\section{Statistical Analysis:}

Two way analysis of variance for the data was done using the SAS General Linear Model Procedure (SAS Institute, 2000). Mean values were compared using Duncan's Multiple Rang Test, (Duncan, 1955) when significant differences existed. The significance level was set at 5\%. 


\section{RESULTS AND DISCUSSION}

\section{A-) Physiological Indicators}

\section{A-1) Rectal Temperature:}

Heat stress, in general and within each cage density, resulted in a significant increase in rectal temperature (Figs. 1 and 2). Birds exposed to heat stress had significantly higher rectal temperature, at the first and last days of heat stress, as compared to their corresponding controls. The rise in rectal temperatures, in response to high environmental temperature, was previously reported (Cheng et al., 1990; Servet et al., 1997; Wolfenson et al., 2001). They considered that rectal temperature is a good indicator of both heat stress and acclimation. However, the rise in rectal temperature, at the first day $\left(44.68 \pm 0.07\right.$ vs $\left.40.98 \pm 0.02^{\circ} \mathrm{C}\right)$ of heat exposure (Fig. 1), was higher than those at the last day $\left(43.33 \pm 0.04 \mathrm{vs} 40.94 \pm 0.02^{\circ} \mathrm{C}\right)($ Fig. 2$)$ of heat stress for all cage densities. This indicated that, some acclimation took place.

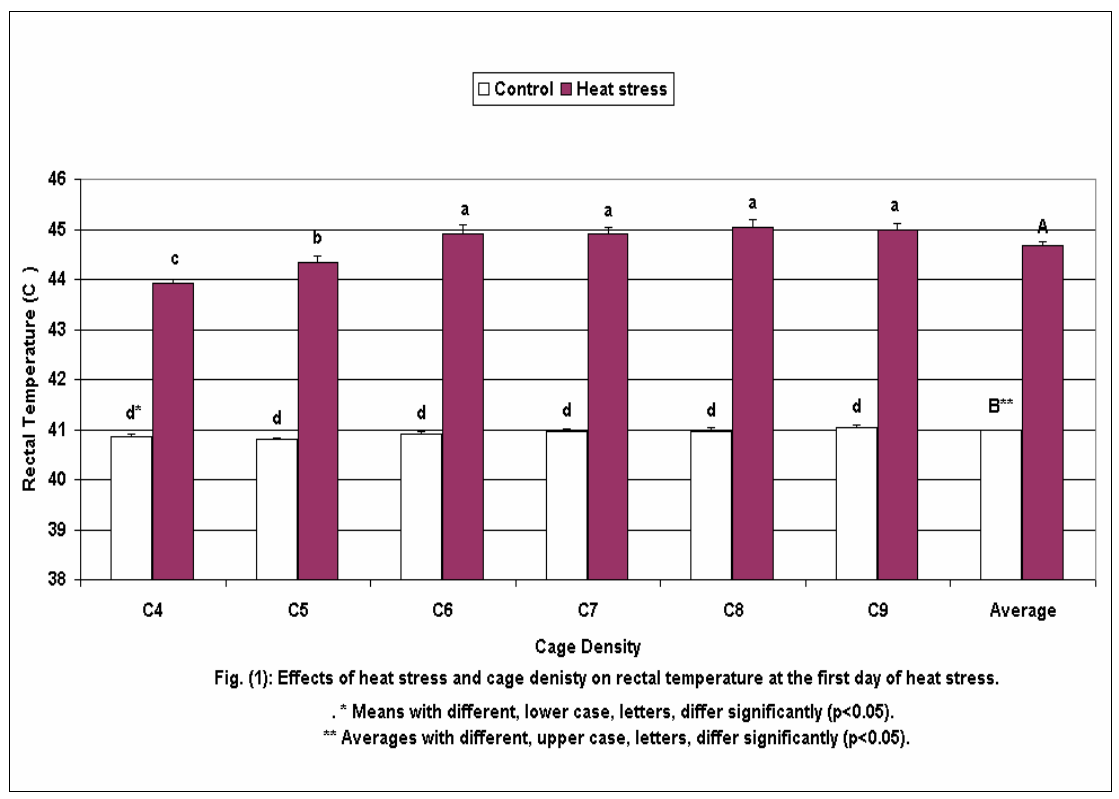

Rectal temperatures of heat stressed birds in the $\mathrm{C}_{6}$ to $\mathrm{C}_{9}$ cages were significantly higher than those in the $\mathrm{C}_{4}$ and $\mathrm{C}_{5}$ cages, at the first and last days of heat stress (Figs. 1 and 2 ). At the first day of heat stress, birds in the $\mathrm{C}_{4}$ cages had significantly lower rectal temperatures than those in the $\mathrm{C}_{5}$ cages. However, there were no significant differences in rectal temperatures between these two cage densities, on the last day of heat stress. This would indicate that, under heat stress condition, it is advisable to give the laying hens more space. 


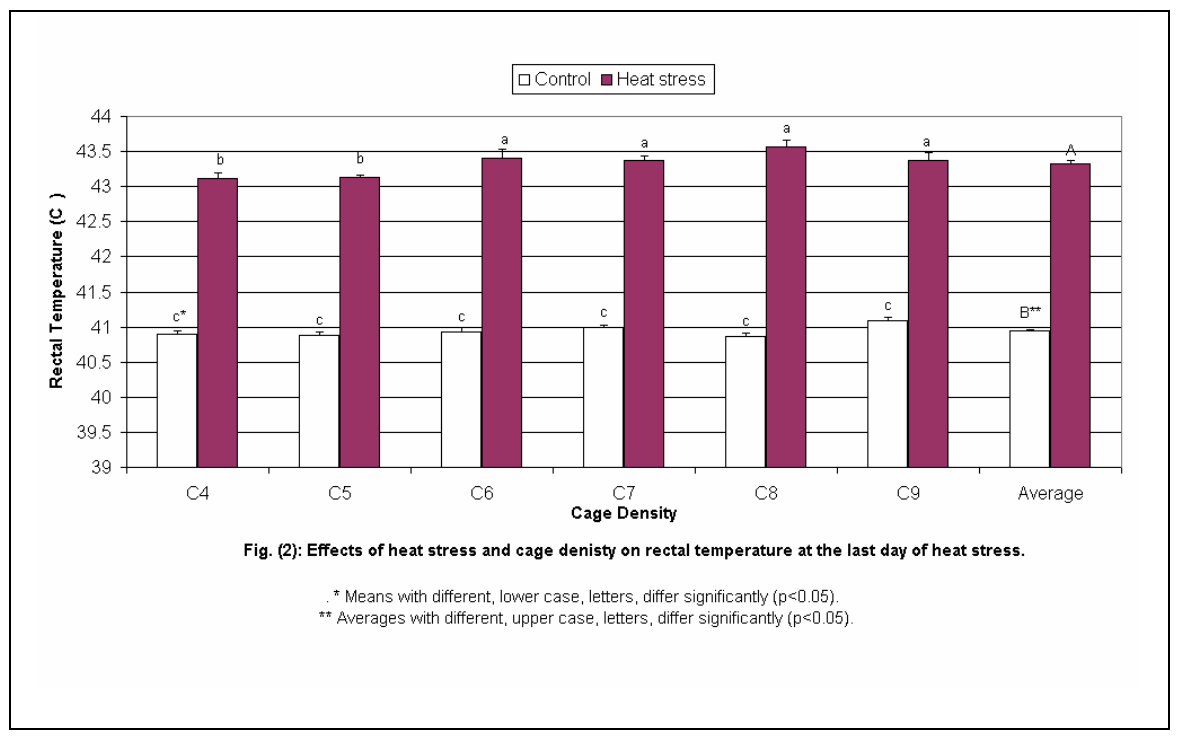

\section{A-2) Physiological Properties:}

\section{A-2-a) Total Red Blood Cell Counts (RBC's):}

Hens exposed to heat stress had significantly lower RBC's, by about 23.15 and $16.87 \%$, as compared to control hens, at the first and last days of heat stress, respectively (Figs. 3 and 4). The reduction in RBC's, in heat stressed birds, were also observed by Sahota et al. (1994) and Rautela et al. (1994). The observed significant effect of heat stress on RBC's count, within cage density, was not present, when hens were caged at 9 birds/cage, at the first day of heat stress (Fig. 3). At the last day of heat stress, the same trend was observed in the 8 and 9 birds per cage densities (Fig. 4). These results may be due to more competition during drinking.

The reduction in RBC's, per unit volume of blood, may be due to hemodillution, due to increased water consumption during the heat stress period. Similar observations were reported by Sturkie (1986). He stated that the numbers of RBC's are dependent on both the numbers of new RBC's produced and the average life span of the old cells. Hence, heat stress may shorten the RBC's life span, resulting in a decrease total numbers of RBC's.

Results also indicated that, under heat stress, birds housed at low cage densities $\left(C_{4}\right.$ and $\left.C_{5}\right)$ had lower RBC's than those housed at high cage densities $\left(C_{8}\right.$ and $\left.C_{9}\right)$, at the first and last days of heat stress (Figs. 3 and 4). However, these differences were not statistically significant. The reduction in $\mathrm{RBC}$ 's for hens in the $\mathrm{C}_{4}$ and $\mathrm{C}_{5}$ cages may be due to the increase in water consumption as compared to those in the $\mathrm{C}_{8}$ and $\mathrm{C}_{9}$ cages, due to less competition during drinking. Opposite results were observed, under the no heat stress conditions. These results indicated that, the effect of density on RBC's count was related to the ambient temperatures. 


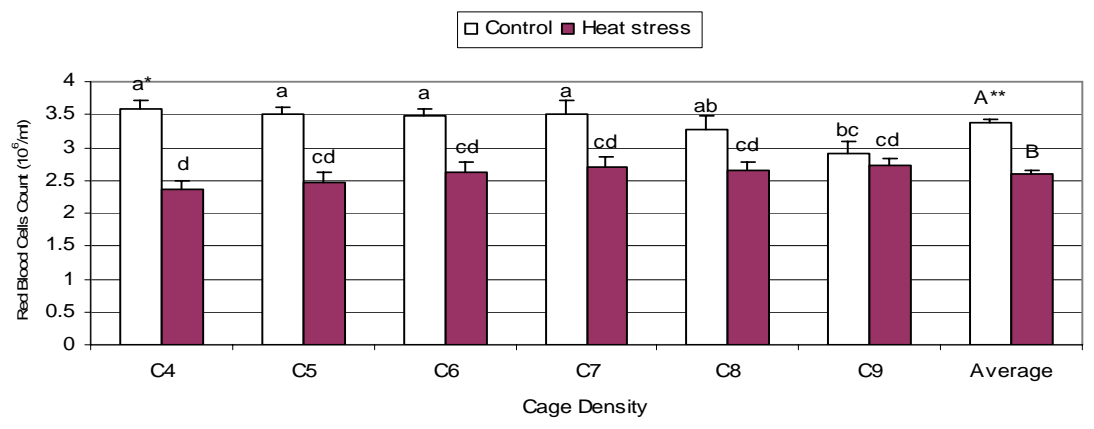

Fig. (3): Effects of heat stress and cage denisty on red blood cells count at the first day of heat stress.

* Means with different, lower case, letters, differ significantly $(\mathrm{p}<0.05)$.

** Averages with different, upper case, letters, differ significantly $(\mathrm{p}<0.05)$.

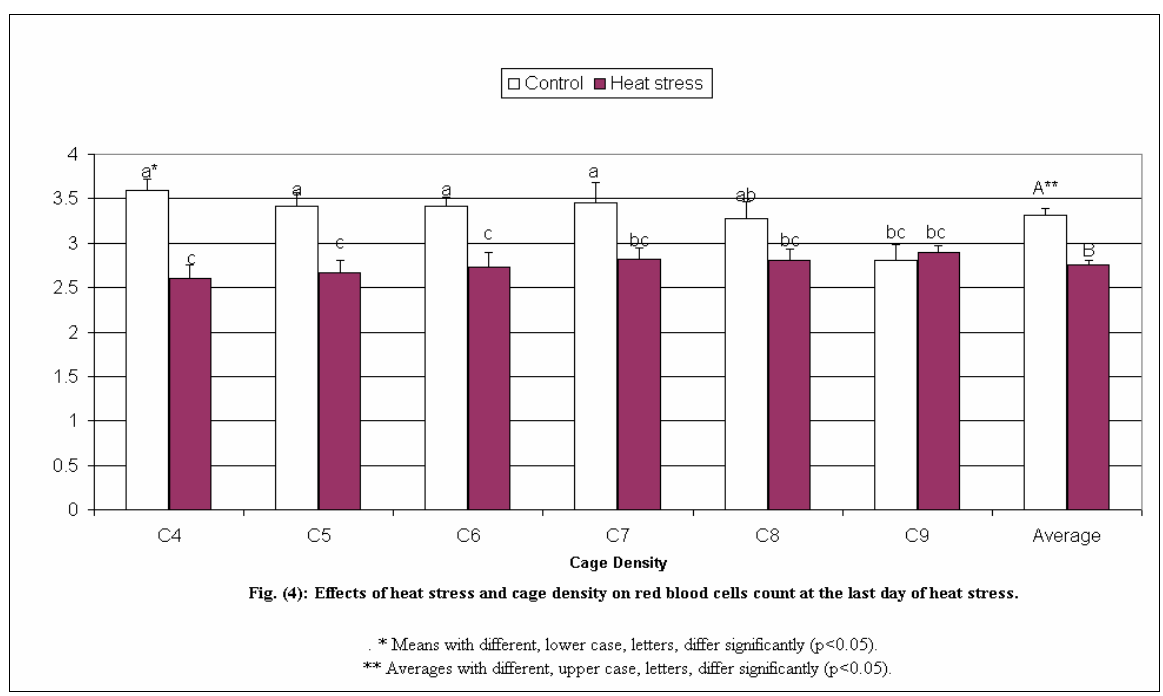

\section{A-2-b) Packed Cell Volume (PCV):}

Results indicated that hens, under heat stress conditions, had significantly lower PCV, by about 14.76 and $11.91 \%$, as compared to the control hens, at the first and last days of heat stress, respectively (Figs. 5 and 6). These results are in agreement with the finding of Rautela et al. (1994) and Yahav and Hurwitz (1996). They reported that, heat stressed birds had significantly lower PCV than non-heat stressed ones. 

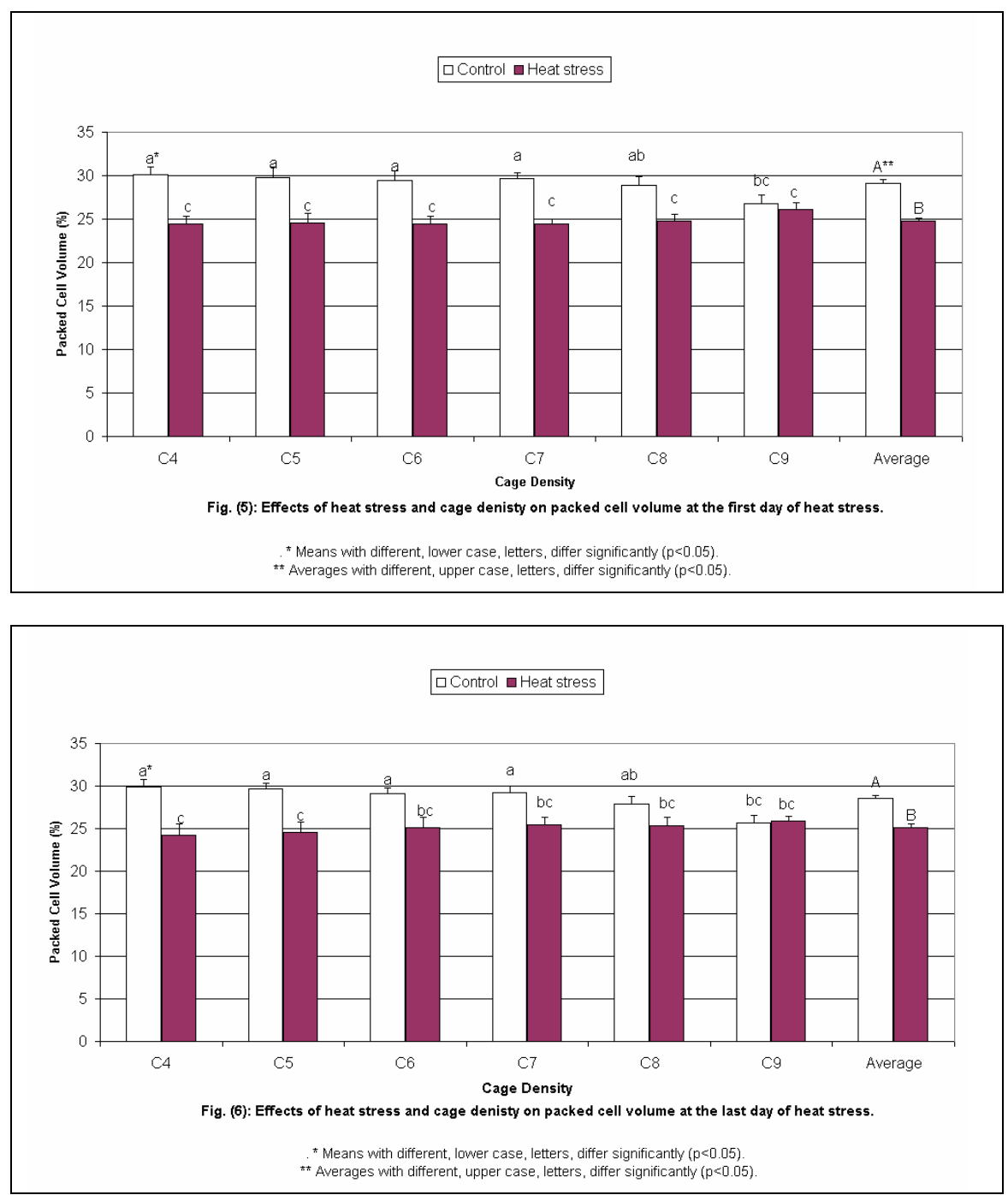

When birds were placed nine to a cage (at the first day of heat stress) or 8 and 9 to a cage (at the last day of heat stress) their PCV did not drop, due to the heat stress, as it happened with all other densities (Figs. 5 and 6). The PCV of the 8 and 9 birds per cage was reduced due to the cage density, thus it did not further dropped due to heat stress.

\section{A-2-c) Hemoglobin Concentration (HbC):}

The hemoglobin concentrations, in general, at the first and last days of heat stress, for heat stressed hens, were significantly lower as compared to non-heat stressed hens (Figs. 7 and 8). Similar results were obtained by Vo et al. (1978) and Rautela et al. (1994). They reported that high environmental temperature caused a decrease in $\mathrm{Hb}$ 
concentration. At the last day of heat stress, when 7, 8 or 9 hens were caged together, the decline in $\mathrm{HbC}$ was not significant.
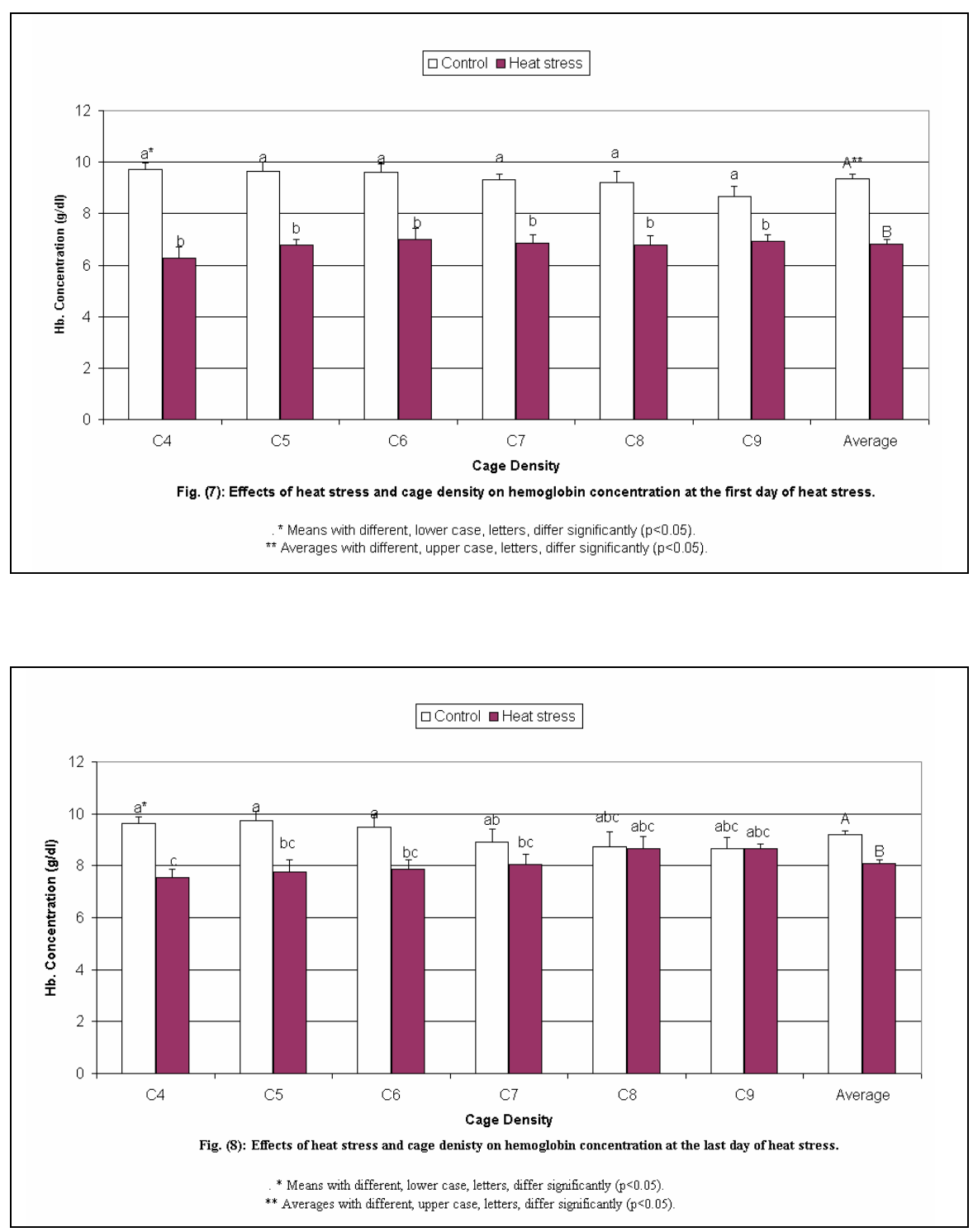

There were no significant differences in $\mathrm{HbC}$ between all cage densities, within the heat stressed or the control groups, (Figs. 7 and 8). In general, heat stress causes a decrease in total RBC's, which in turn caused a decreased $\mathrm{HbC}$ and $\mathrm{PCV}$. This is due to the positive relationships between RBC's, HbC and PCV (Sturkie, 1986). 
A-3) Blood Chemical Constituents:

A-3-a) Plasma Protein, Albumin and Globulin Levels:

Plasma total proteins has been used as an indicator of the effect of heat stress on chickens (Kutlu and Forber, 1993; Berrong and Washburn, 1998). Regardless of cage density, in most cages, hens subjected to heat stress had significantly decreased plasma total protein, albumin and globulin levels, as compared to control hens, at the first day of heat stress (Figs. 9, 11 and 13). At the last day of heat stress, plasma total protein and globulin levels, for heat stressed hens, were significantly lower than those of the control ones (Figs. 10 and 14). These results are in agreement with the findings of Makind and Fatunmbi (1985) and Faltas et al. (1987). They reported that, blood protein concentration decreased significantly, when birds were exposed to heat stress. This decline in blood protein levels, in heat-stressed birds, may be due to reduced protein synthesis. This observation is in agreement with Ahmed et al. (1967). They indicated that exposing birds to high ambient temperature leads to a decrease in protein synthesis.

Within cage density, hens housed from 4 to 7 per cage did not show a significant decrease in albumin levels, at the first day of heat stress (Fig. 11), or total protein levels, on the last day of heat exposure (Fig. 10). On the last day of heat stress, the observed significant effects of heat stress, on albumin levels, were only present when 9 hens were caged together (Fig. 12).

Results also indicated that, there were no significant differences in plasma total protein, albumin and globulin levels due to the cage density (Figs. 9 to 14). The only significant differences were observed, when hens housed nine to a cage, without exposing them to heat stress, had significantly higher albumin level than the other hens, at the last day of treatment (Fig. 12).

The results of the current study indicated that heat stressed birds, housed at lower cage densities had a less decline in their blood protein levels.

\section{A-3-b) Serum Calcium Levels:}

Subjecting laying hens to high environmental temperatures significantly decreased their serum calcium levels at the first day of heat stress (Fig. 15). However, after 7 days of exposing the birds to the heat stress, there were no significant differences in the serum calcium levels between the heat stressed and the control hens (Fig. 16). These results are in agreement with the findings of Arad et al. (1993) and Usayran et al. (2001). They reported that, high environmental temperatures significantly decreased the serum or plasma calcium concentrations. The significant decrease in serum calcium, at higher temperatures, could be a consequence of the significant decrease in feed intake (Usayran et al., 2001). Also, Odom et al. (1986) found that, under heat stress conditions, free calcium, in the hen's blood, decreased during the development of respiratory alkalosis, that resulted from thermal panting.

The decline in serum calcium levels, due to heat stress, at the first day of heat stress, were significant only in the higher cage densities $\left(\mathrm{C}_{8}\right.$ and $\left.\mathrm{C}_{9}\right)$ (Fig. 15). Hens housed at the highest cage density $\left(\mathrm{C}_{9}\right)$ had significantly lower serum calcium levels than any of the other cage densities, either at the first day or at the last day of heat 

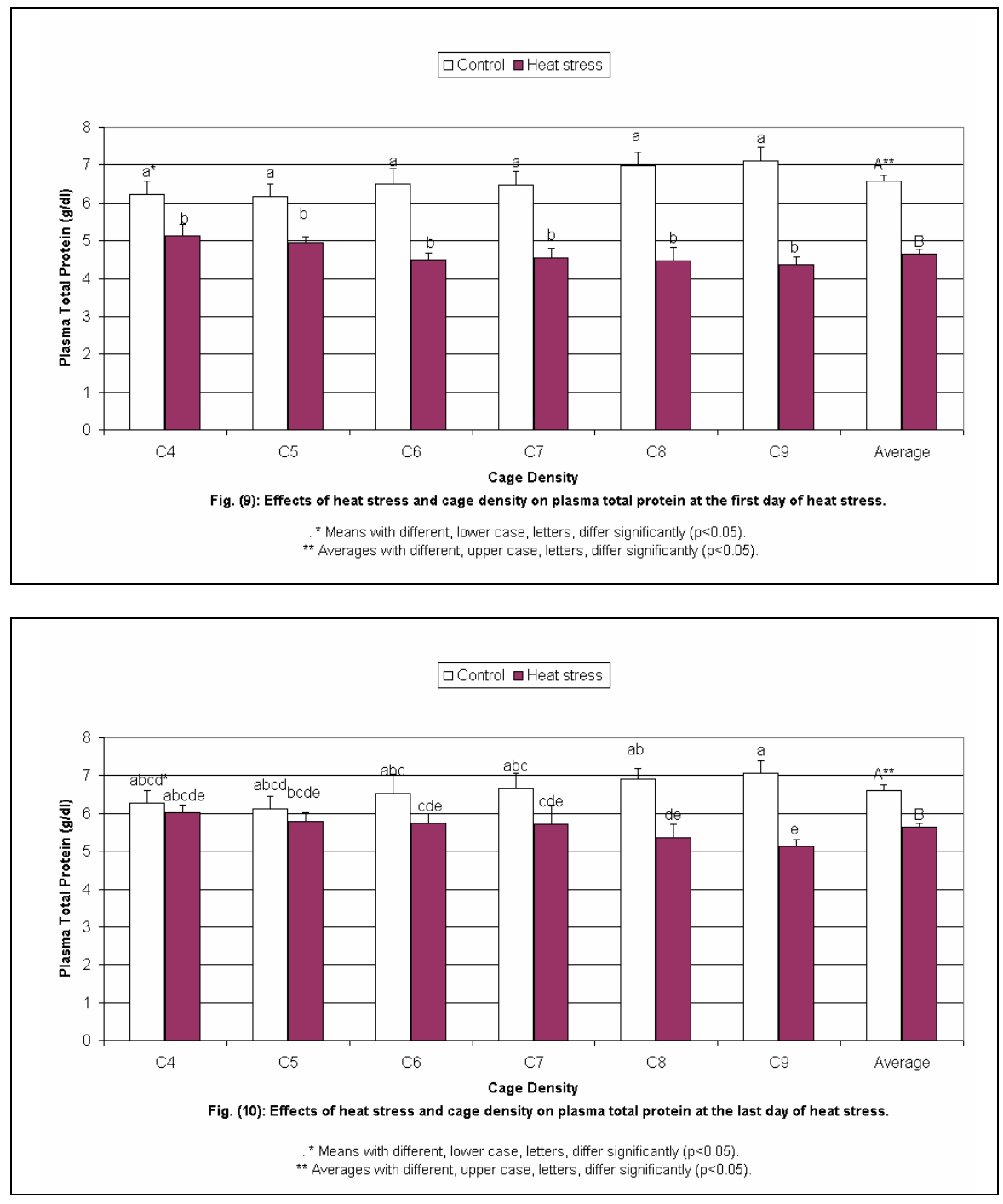

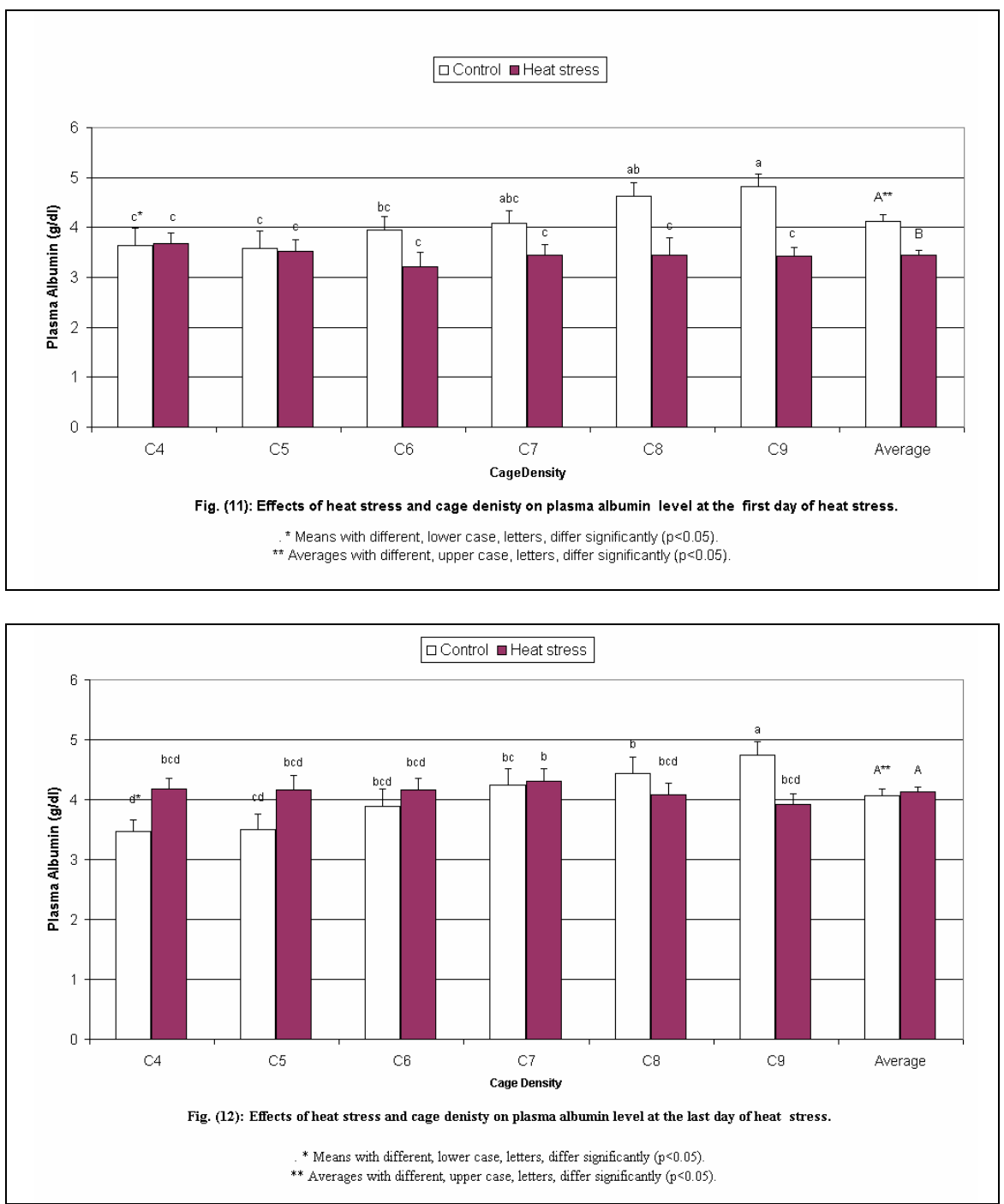

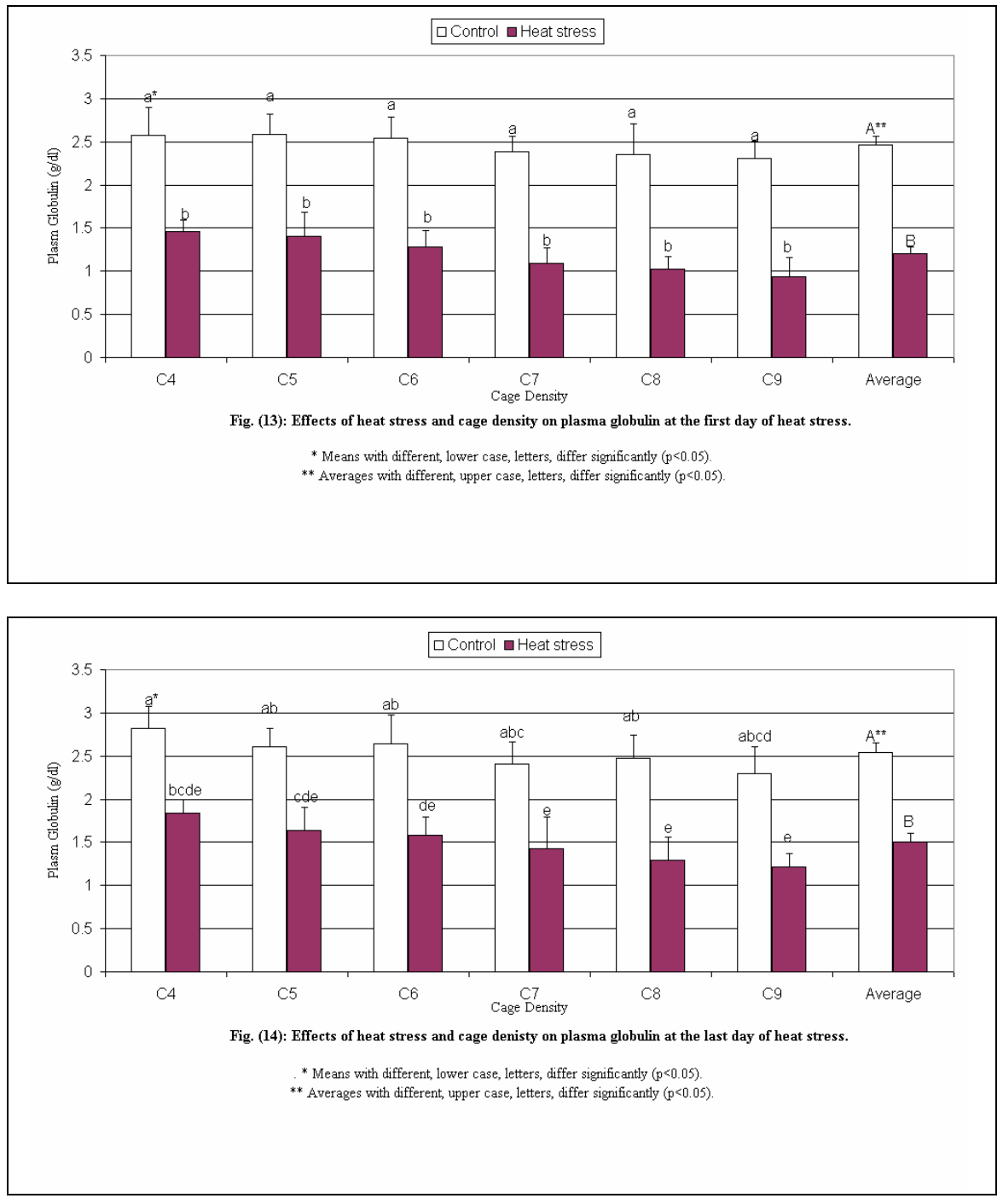

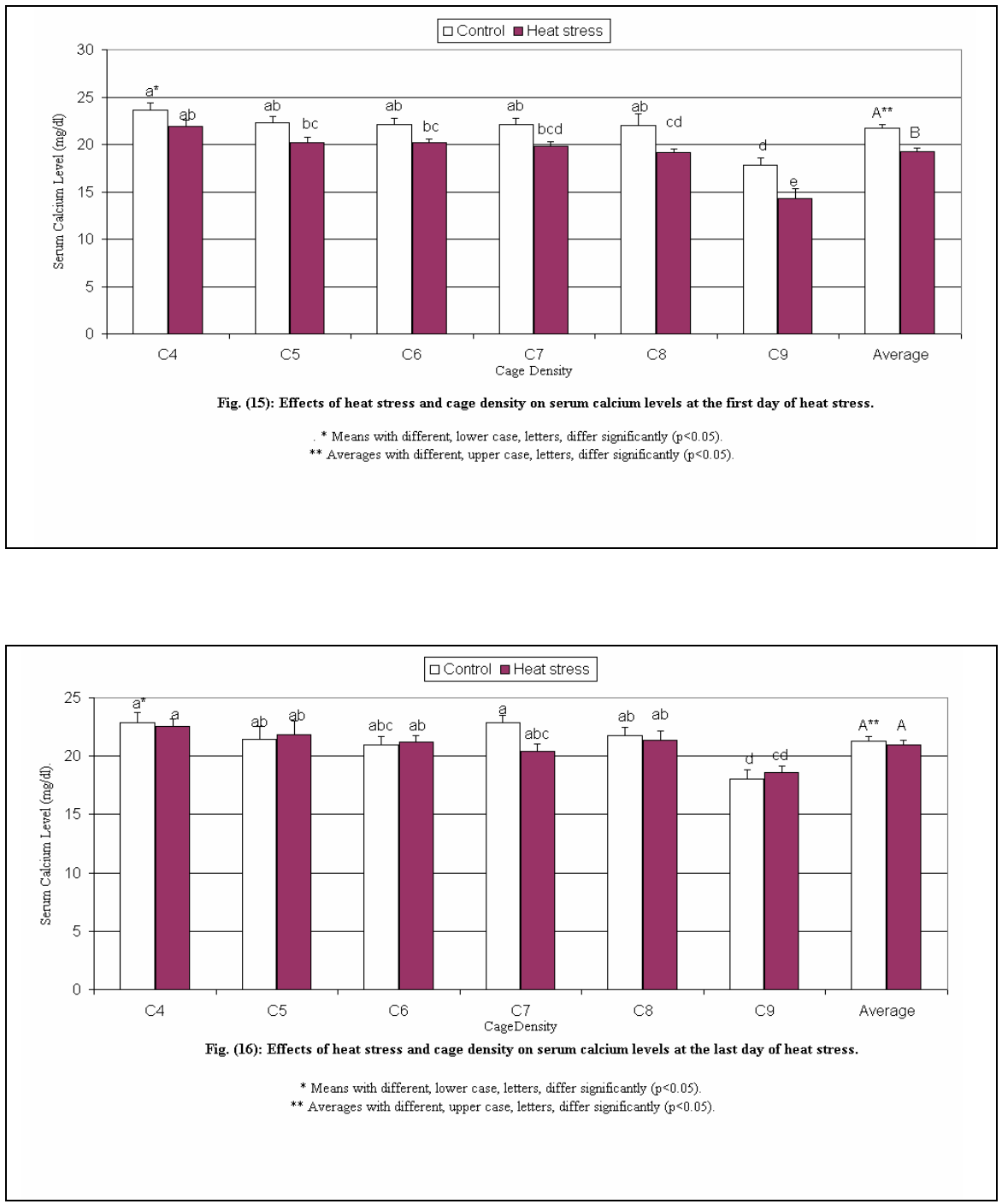
stress (Figs. 15 and 16). This is probably due to the heat stress and the high cage density, since both the heat stressed and the crowded hens had significantly lower serum calcium levels. This may be due to the decreased feed intake. Gharib et al. (2005) reported that decreasing cage floor space per bird, from 750 to $333 \mathrm{~cm}^{2}$ significantly decreased feed consumption and serum calcium levels.

\section{A-3-c) Serum Potassium Levels:}

Hens exposed to heat stress had significantly lower serum potassium levels, as compared to control hens, at the first and last days of heat stress (Figs. 17 and 18). These results are in agreement with Ait-Boulahsen et al. (1989). They reported that elevation of body temperatures to $44.5-45.0^{\circ} \mathrm{C}$, by exposing chickens to $40-42^{\circ} \mathrm{C}$ ambient temperatures is associated with decreased plasma potassium. They also stated that, a substantial shift in the plasma concentration of the major ions (potassium, is one of them) can cause serious disturbance to cells since these ions and the plasma proteins play a major role in establishing the osmotic balance between plasma and fluids bathing the cells. The concentrations of the major ions are also important in determining the $\mathrm{pH}$ of the body fluids.

Within cage density, at both the first and last days of heat stress, the results indicated that, hens housed at the lowest cage density $\left(\mathrm{C}_{4}\right)$ did not show the detrimental effect of heat stress on serum potassium level (Figs. 17 and 18) as it did with other densities.

Heat stressed hens housed at the highest cage density $\left(C_{9}\right)$ had significantly lower serum potassium levels, at the first and last days of heat exposure, than those housed at the lowest cage density $\left(\mathrm{C}_{4}\right)$ (Figs. 17and 18). This is associated with the higher rectal temperatures of hens at the higher cage densities (Figs. 1and 2). No previously reported studies included the influence of cage density, on serum potassium levels, under high environmental temperatures.

Blood chemical constituents data indicated that hens caged at low densities (4 or 5 birds/cage) responded less intensely to heat stress than hens at higher cage densities. Specifically, hens housed at 4 or 5 hens/cage showed increased resistance to heat exposure. This was indicated by a less decline in plasma proteins, and higher serum calcium, and potassium levels, as result of heat stress, when compared to hens caged at higher densities.

A-4) Heterophil:Lymphocyte (H:L) Ratio:

Hens exposed to heat stress had significantly higher H:L ratio as compared to controls, at the first and last days of heat stress (Figs. 19 and 20). The increase in H:L ratio in heat stressed birds were also observed by McFarlane et al. (1989) and Hester et al. (1996b). At the last day of heat stress, within cage density, H:L ratio was not affected by heat stress, when hens were caged at the lowest density $\left(\mathrm{C}_{4}\right)$ (Fig. 20).

Under heat stress conditions, hens housed at higher cage densities $\left(\mathrm{C}_{8}\right.$ and $\left.\mathrm{C}_{9}\right)$ had significantly higher $\mathrm{H}$ :L ratio than those housed at the lowest cage density $\left(\mathrm{C}_{4}\right)$, at the first and last days of heat exposure (Figs. 19 and 20). These results indicates that, under heat stress conditions, lymphopenia was more pronounced in the higher cage densities birds than in the lower densities. Hester et al. (1996b) reported that hens kept in single-bird cages $\left(1085 \mathrm{~cm}^{2}\right.$ per bird) had lower $\mathrm{H}$ :L ratios $(34.4 \%)$ than those kept in multiple-bird cages $(42.6 \%)$ at $362 \mathrm{~cm}^{2}$ per bird. The increased in H:L ratio for hens, at high cage densities, under heat stress conditions, could indicate that the birds are more affected by social competition than those at low cage densities. 

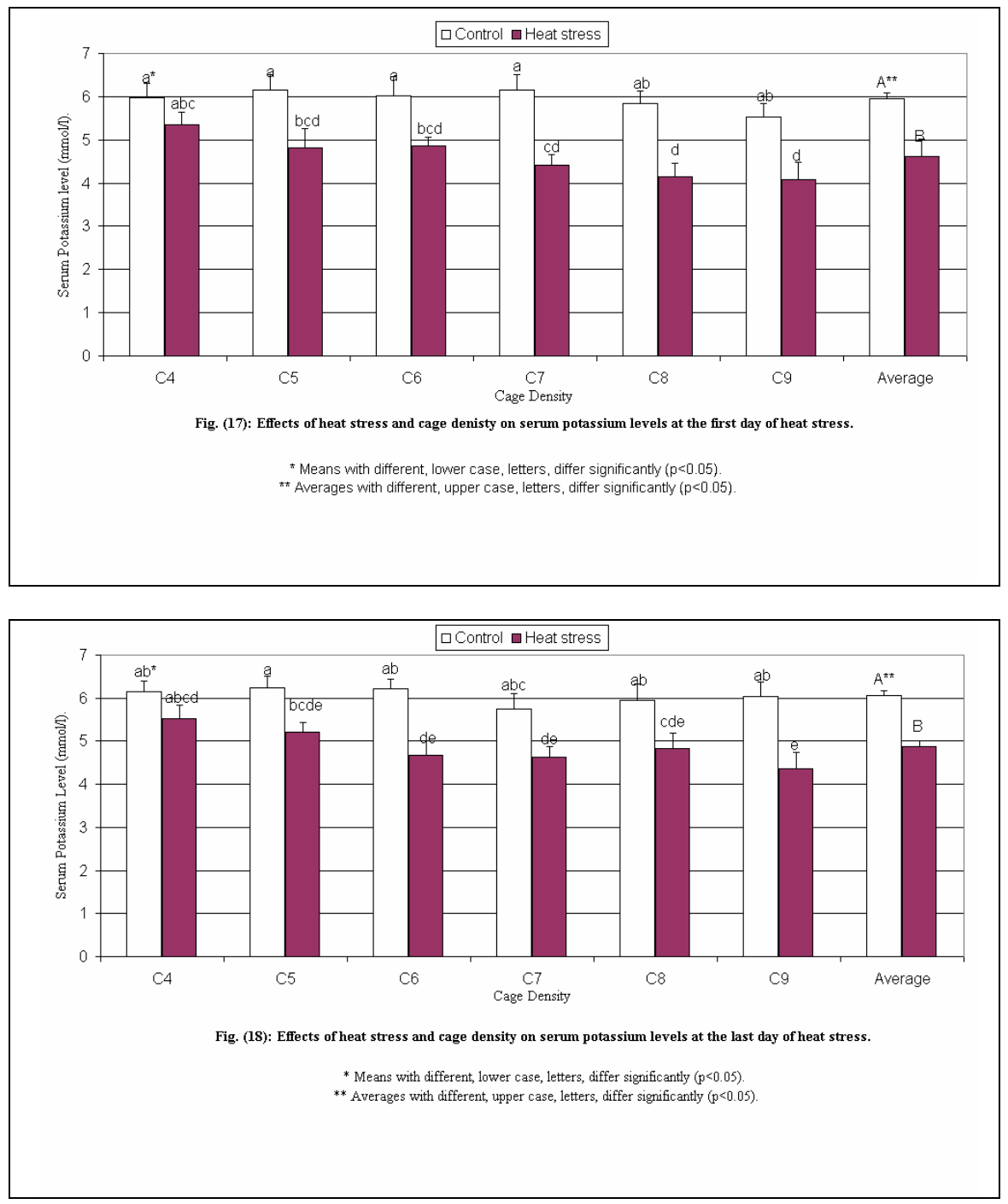

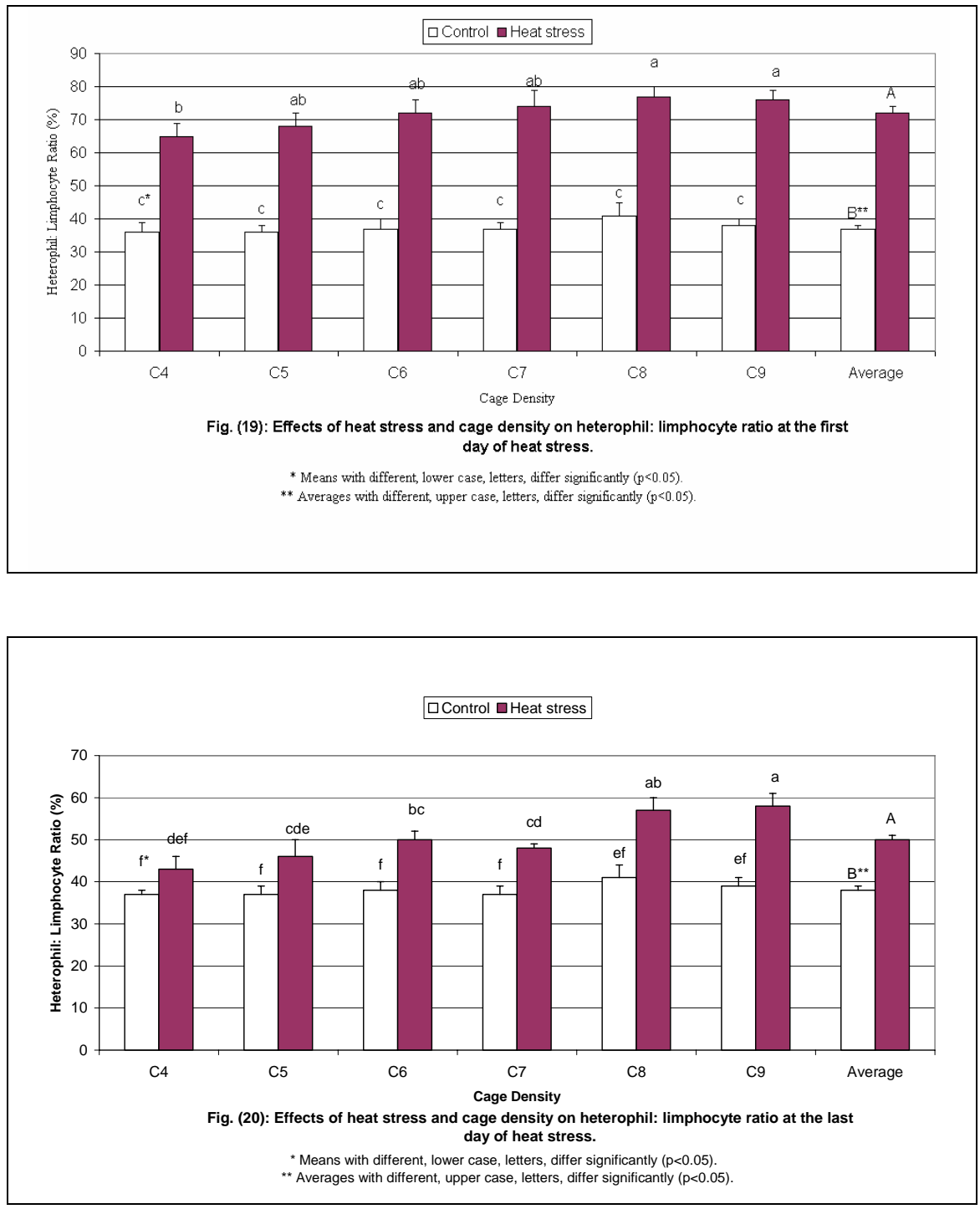
On the other hand, there were no significant differences, in $\mathrm{H}: \mathrm{L}$ ratios between cage densities, under the no heat stress conditions.

Our results indicated that $\mathrm{H}: \mathrm{L}$ ratio is a sensitive indicator of heat stress in the fowl. The increased H:L ratios were apparent, at the first and last days of heat stress. This support the idea that leukocyte changes, in response to environmental stress, are stabile and enduring. Our observations, support the finding of James et al. (1989).

\section{B) Immune Response:}

\section{Antibody Titers against SRBC's:}

Hens exposed to heat stress had significantly lower antibody titers against SRBC's on days 3, 5 and 7 post immunization as compared to the controls (Figs. 21, 22 and 23). Similar results were obtained by Donker et al. (1990); Hester et al. (1996a) and Atta (2002). They reported that, heat exposure significantly reduces the antibody titers against SRBC's. Also, Thaxton and Siegel (1970, 1972, 1973), Subba Rao and Glick (1970, 1977) and Regnier et al. (1980) reported suppressive actions of heat stress on the humoral immune responses for chickens.

The observed significant suppression effects of heat stress on antibody titers against SRBC's, within cage density, were only present when hens were housed at 9 hens to a cage, on day 3 post immunization (Fig. 21). On days 5 and 7 post immunization, this significant suppression effect was observed, within all cage densities, except, when 5 hens were placed in a cage, on day 5 post immunization (Fig. 21 and 22)

Birds housed at higher cage densities $\left(\mathrm{C}_{8}\right.$ and $\left.\mathrm{C}_{9}\right)$, under heat stress or control conditions, produced significantly less antibody titers against SRBC's than those housed at the lowest cage density $\left(\mathrm{C}_{4}\right)$, on day 5 post immunization (Fig. 22). This is in agreement with the findings of Hester et al. (1996a). They reported that birds housed in multiple-bird cages $\left(362 \mathrm{Cm}^{2}\right.$ floor area/bird) had significantly lower antibody titers against SRBC's than those in single-bird cages $\left(1085 \mathrm{Cm}^{2}\right.$ floor area / bird), when birds were subjected to high environmental temperature $\left(38^{\mathrm{O}} \mathrm{C}\right)$.

Under stress conditions, due to physical stressor (Siegel, 1987) or high density (Mashaly et al., 1984), more corticosteroids were found to be bound in the thymus cells of chicken. The immunosuppression observed in our study, due to the heat stress or high cage density, could be partially mediated by corticosteroid-binding in the lymphoid cells.

On the other hand, under heat stress conditions there were no significant effects due to cage density, on antibody titers against SRBC's, 7 days post immunization (Fig. 23). The HI titers ranged from 3.0 to 4.4 ( $\log 2)$. The higher titers were observed when hens were caged at lower densities.

The changes observed in the antibody titers against SRBC's and in the H:L ratios, due to heat stress and cage density, provided evidence of improved hens adaptation, at lower cage densities, to high environmental temperatures. 

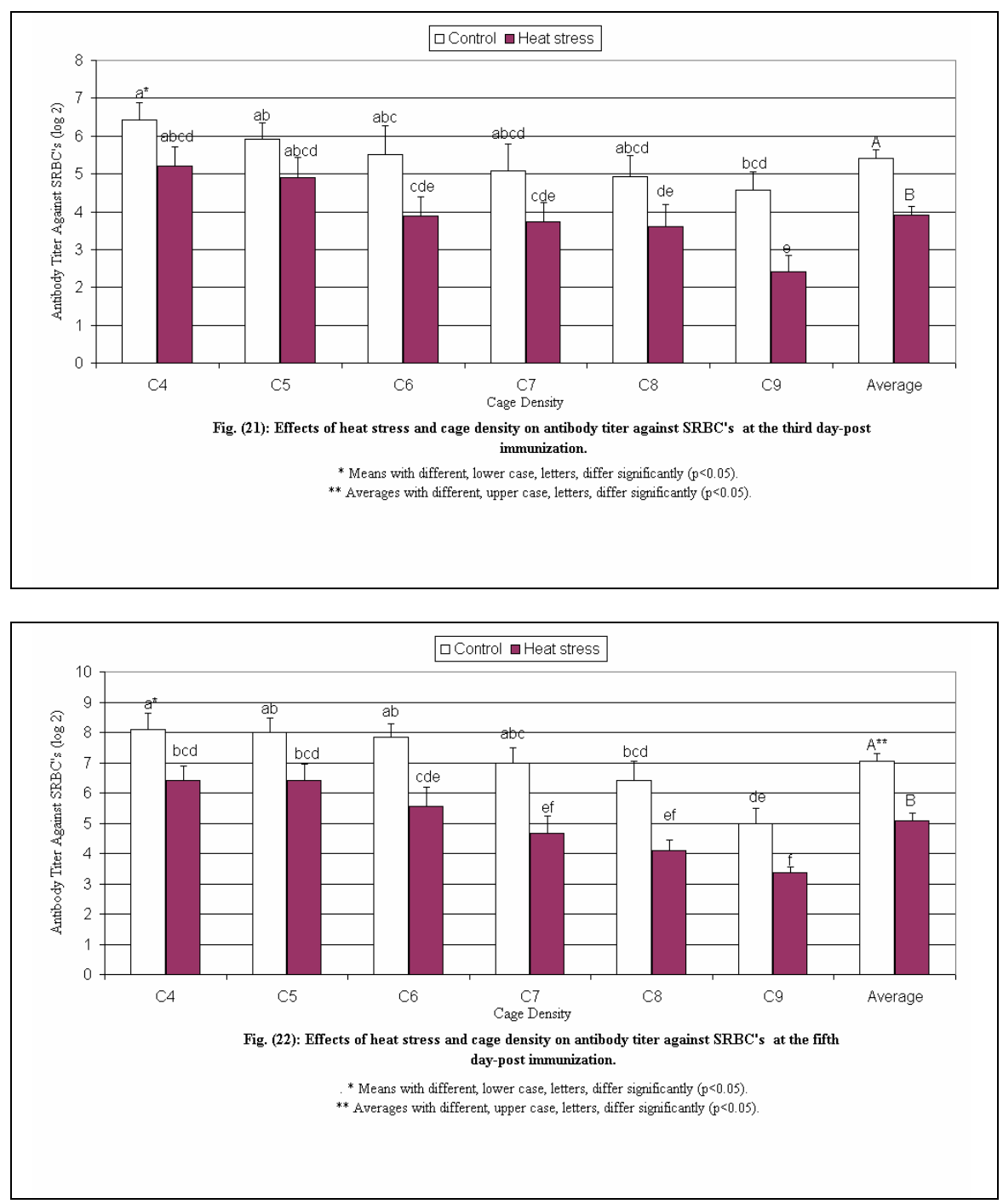


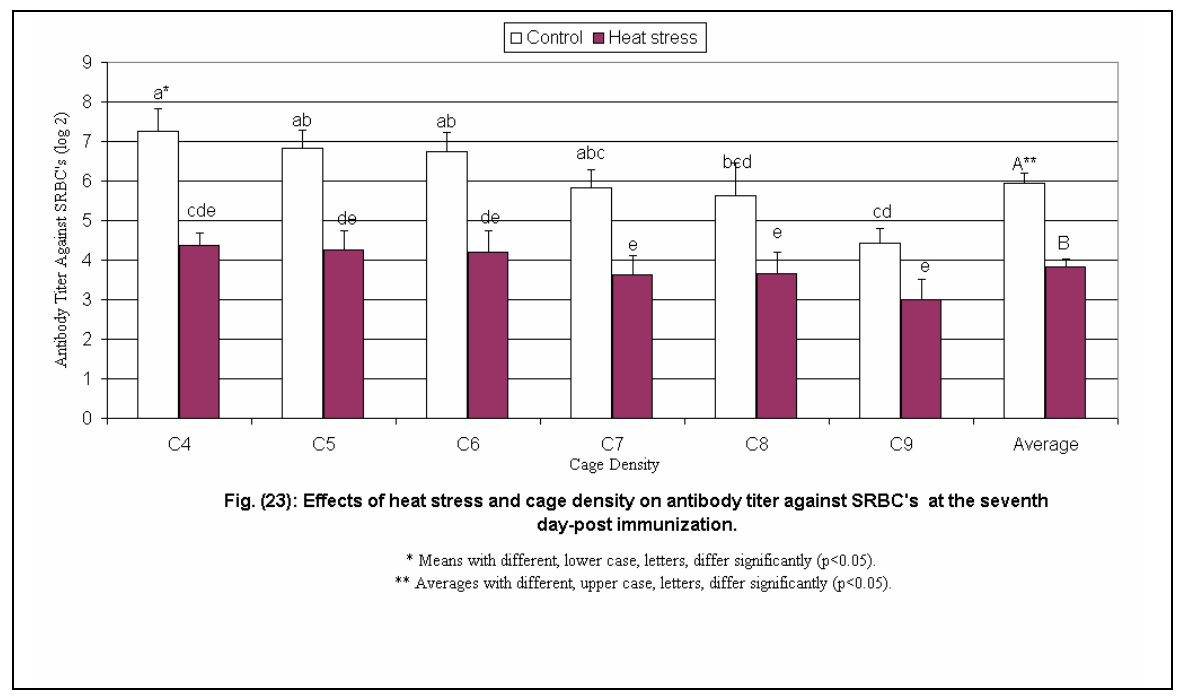

\section{CONCLUSION}

Our results indicated that, hens caged at low densities resist heat stress more than hens caged at high densities. The physiological indicators and immune response of hens, at different cage densities, that were subjected to heat stress, provided proofs that hens at low cage densities $\left(750\right.$ or $600 \mathrm{~cm}^{2} /$ bird $)$ were more resistance to heat stress. Hens housed at low cage densities (750 or $600 \mathrm{~cm}^{2} /$ bird) had lower rectal temperature, less decline in blood proteins levels and higher serum calcium and potassium levels, when compared to hens at higher densities $(428,375$ or 333 $\mathrm{cm}^{2} /$ bird). In additional, heat stressed hens, at low cage densities, had higher immune response against SRBC's and lower H:L ratios, than those at higher densities.

Housing hens at lower cage densities alleviated the detrimental effects of heat stress on plasma proteins, serum calcium and potassium levels. Also, antibody titers against SRBC's and H:L ratios were not affected by heat stress, when hens were caged at lower densities.

It could be concluted that, housing commercial layers at an area of at least 600 $\mathrm{cm} 2 /$ bird, is an effective method to alleviate the effects of heat stress, when conventional open-sided houses are used, in hot climate countries .

\section{REFERENCES}

Ahmad, M. M., R. E. Moreng and H. D. Muller, 1967. Breed response in body temperature to elevated environmental temperature and ascorbic acid. Poultry Sci. 46: 6-15. 
Ait-Boulahsen, A., J. D. Garlich and F. W. Edens, 1989. Effect of fasting and acute heat stress on body temperature, blood acid-base and electrolyte status in chickens. Comparative Biochemistry and physiology 94A, 683 - 687.

Arad, Z., M. S. El-Sayed and J. H. Brackenbury, 1993. Effect of acute heat exposure on blood flow and its distribution in the unrestrained laying fowl (Gallus domesticus). Br. Poultry Sci., 34: 559 - 568.

Atta, A.M.M., 2002. Influence of supplemental ascorbic acid on physiological and immunological parameter of broiler chicks during heat stress condition. Egypt. Poultry Sci., 22: 793-814.

Belay, T. and R. G. Teeter, 1993. Broiler water balance and thermobalance during thermoneutral and high ambient temperature exposure. Poultry Sci., 72: 116-124.

Belay, T. and R. G. Teeter, 1994. Virginiamycin effects on performance and sellable carcass of broilers. J. Appl. Poultry Res., 3: 111-116.

Berrong, S. L. and K. W. Washburn, 1998. Effects of genetic variation on total plasma protein, body weight gains and body temperature responses to heat stress. Poultry Sci., 77: 379 - 385.

Blem, C. R., 2000. Energy balance. Avian Physiology. $5^{\text {th }}$ ed. G. C. Whittow, ed. Academic press, New York. NY. P, 327 - 341.

Brake, J. T., 1989. Role of ascorbic acid in poultry production: ascorbic acid, stress and immunity. Zootech. Int. January: 37 - 40.

Cheng, T. K., C. N. Craig and H. L. Melvin, 1990. Effect of environmental stress on the ascorbic acid requirement of laying hens. Poultry Sci., 69: $774-780$.

Collins, A., S. Duthile and M. Ross, 1994. Micronutrients and oxidative stress in the aetiology of cancer. Proceedings of the Nutrition society, 53: 67-75.

Dawson, w. R. and G. C. Whittow, 2000. Regulation of body temperature. Avian Physiology. 5 th ed. G. C. Whittow, ed. Academic press, New York. NY. P, 343 390.

Deyhim, F. and R. G. Teeter, 1990. Acid base balance and plasma corticosterone of heat distressed broilers consuming $\mathrm{KCL}$ and $\mathrm{NaCl}$ supplemental drinking water. Poultry Sci., 69: 163. (Abstr.).

Donker, R. A., M. G. B. Nieuwland and A. J. Van der Zijpp, 1990. Heat stress influences on antibody production in chicken lines selected for high and low immune responsiveness. Poultry Sci., 69: 599 - 607.

Duncan, D. B., 1955. Multiple F-test. Biometrics, 11: 1 - 42.

Etches, R. J., T. M. John and A. M. Verrinder Gibbins, 1995. Behavioral, physiological, neuroendocrine and molecular responses to heat stress. In: Poultry production in hot climates. Chapter (3), pp 32 - 48. Cab International.

Faltas, A. A., A. K. I. Abd-Moty and Kh. A. Mohamed, 1987. The effect of exposure at $40^{\circ} \mathrm{C}$ on the physiological response of the domestic fowl minting at $16^{\mathrm{O}} \mathrm{C}$. Minia J. Agric., res. \& Dev. Vol. 9 No. 1: 383 - 398.

Ferket, P. R. and M. A. Qureshi, 1992. Performance and immunity of heat stressed broilers fed vitamin-and electrolyte-supplemented drinking water. Poultry Sci., 71: 88 - 97.

Gharib, H. B. A., F. K. R. Stino, A. A. Attalla and M. A. EL-Menawey, 2005. Effect of cage density and housing system on productive performance and physiological indicators of white Leghorn type layers. Egypt. Poultry Sci., 25: in press.

Gross, W. B. and H. S. Siegel, 1983. Evaluation of the heterophil /lymphocyte ratio as ameasure of stress in chickens. Avian Dis. 27:972-979. 
Hartman, F. A. and M. A. Lessler, 1963. Erythrocyte measurements in birds. Auk., 80: 476. (cited by sturki, 1986).

Henry, R. F., 1974. "Clinical chemistry Principles and technics" $2^{\text {nd }}$ Ed. Harpper and Raw. New York, 644-646.

Hester, P. Y., W. M. Muir and J. V. Craig, 1996a. Group selection for adaptation to multiple-hen cages: Humoral immune response. Poultry Sci., 75: 1315 - 1320.

Hester, P. Y., W. M., Muir, J. V. Craig and J. L. Albright, 1996b. Group selection for adaptation to multiple-hen cages: Hematology and Adrenal function. Poultry Sci., 75: 1295 - 1307.

Hunsaker, W. G., 1969. Species and sex differences in the percentage of plasma trapped in packed cell volum determination on avian blood. Poultry Sci. 48:907.

James, M., Mc Farlane and Stauley E. Curtis, 1989. Multiple concurrent in chicks 3. Effect on plasma coticostrone and the heterophil : lymphocyte ratio. Poultry Sci. 68: 522-527.

Klasing, K. C. and B. Benson, 1990. Nutritional implications of an immune response. In seventh annual Carolina Poultry nutrition Conf. Dec., pp. 89 -97.

Kutlu, H. R. and M. Forbes, 1993. Changes in growth and blood parameters in heatstressed broiler chicks in response to dietary ascorbic acid. Livestock Prod. Sci., 36: $335-350$.

Liu, F. H., Z. Q. Xie, Sun, C. L., Z. B. Qian and C. Wand, 1997. Effects of high temperature on blood biochemical parameters and productivity in laying hens. Chinese Journal on Animal Science, 33: 23 - 25.

Makind, M. O. and O. O. Fatunmbi, 1985. Some hematological and biological values of turkeys in ibadan. Bulletin of Animal Health and Production in Africa, 33: 245 $-248$.

Mashaly, M. M., M. Webb, S. L. Youtz, W. B. Roush and H. B. Graves, 1984. Changes in serum corticosterone concentration of laying hens as a response to increased population density. Poultry Sci.63: 2271-2274.

McFarlane, J. M., S. E. Curtis, J. Simon and O. A. Lzguierdo, 1989. Multiple concurrent stressors in chicks. 2. Effects on hematologic boycomposition and pathologic traits. Poultry Sci., 68: 510 - 521.

Mench, J. A., A., van Tienhoven, J. A., Marsh, C. C., McCormick, D. L. Cunningham and R. C. Baker, 1986. Effects of cage and floor pen management on behavior, production and physiological stress responses of laying hens. Poultry Sci., 65: 1058 - 1069.

Miller, L. and M. A. Qureshi, 1991. Induction of heat shock proteins and phagocytic function of chicken macrophage following in vitro heat exposure. Vet. Immunol. Immunopathol.

Odom, T. W., P. C. Harrison and W. G. Bottje, 1986. Effects of thermal-induced respiratory alkalosis on blood ionized calcium levels in the domestic hen. Poultry Sci. 65: 570-573.

Pilaski, J., 1972. Vergleichende untersuchungen uberden haemolobinge halt des hunhner undg eschlecht. Arch. Geflugelk., 36: 70.

Rautela, M. S., D. S. Khati and M. C. Joshp, 1994. Effect of the high temperature on some haematological values of Gullus domesticus at $1650 \mathrm{~m}$ altitude. Indian J. of Anim. Sci., 64: 752 - 753.

Reginer, J. A., K. W., Kelly and C. T. Gaakins, 1980. Acute thermal stressors and synthesis of antibodies in chickens. Poultry Sci. 59: 985-990. 
Sahota, A. W., A. H. Gillani and M. F. Ullah, 1994. Hematological studies on heat stress chickens supplemented with ascorbic acid. Pakistan Veterinary Journal, 14: $30-33$.

SAS Institute, 2000. SAS Users Guide. Version 6.12. SAS Institute, Cary. NC.

Servet, Y., S. Petek, O. Sezen and C. Avigdor, 1997. Comparative evaluation of three commercial broiler stoks in hot versus temprate climates. Poultry Sci. 76: 921 929.

Siegel, H. S., 1987. Effects of behavioral and physical stressors on immune responses. Pagee 39-54 in Biology of stress in farm auimals: An Integrative Adroach. P.R Wiepkema and P. W. M van Adrichem, ed. Martinus nijhoff publishers, Dordrecht, the Netherland; Boston, MA; Lancaster, England V.K.

Siegel, P. B., 1989. Stress and Immunity. Proceeding d 14 th National Meeting on Poultry Health and condemnations, College Park, MD., 157 - 160.

Singh, A. B., A. G. Khan and B. S. Gehleut, 1980. The effect of reciprocal crosses between dwarf and normal parents upon blood constituents of their progeny. Br. Poultry Sci., 21: 74 - 79.

Sturkie, P. D., 1986. “Avian Physiology“ (4 th ed.) (P.D. Sturkie, Ed). Springer Verlag, New York, Inc.

Subba Rao, D. S. V. and B. Glick, 1970. Immunosuppressive action of heat in chickens. Proc. Exp. Biol. Med. 133: 445-448.

Subba Rao, D. S. V. and B. Glick, 1977. Effect of cold exposure on the immune response of chickens. Poultry Sci. 56: 992-996.

Thaxton, P. and H. S. Siegel, 1970. Immunodepression in young chickens by high environmental temperature. Poultry Sci. 49: 202-205.

Thaxton, P. and H. S. Siegel, 1972. Depression of secondary immunity by high environmental temperature. Poultry Sci. 51: 1519-1526.

Thaxton, P. and H. S. Siegel, 1973. Modification of high temperature and ACTH induced immunodepression by metyrapone. Poultry Sci. 52: 618-624.

Usayran, N., M. T. Farvan, H. H. O. Awadallah, I. R. Al-Hawi, R. J. Asmar and V. M. Ashkarian, 2001. Effects of added dietary fat and phosphorus on performance and egg quality of laying hens subjected to a constant high environmental temperature. Poultry Sci., 80: 1695 - 1701.

Van der Zijpp, A.J. and F.R. Leenstra, 1980. Genetic analysis of the humoral immune response of White Leghorn chicks. Poultry Sci., 59: 1363-1369.

Vo, K. V., M. A. Boone and W. E. Johnston, 1978. Effect of lifetime ambient temperature on growth, feed and water consumption and various blood components in male and female Leghorn chickens. Poultry Sci., 57: 793 - 803.

Wolfenson, D., D. Bachrach, M. Maman, Y. Graber and I. Rozenboim, 2001. Evaporative cooling of ventral regions of the skin in heat-stressed laying hens. Poultry Sci., 80: 958 - 964.

Yahav, S. and S. Hurwitz, 1996. Induction of thermotolerance in male broiler chickens by temperature conditioning at an early age. Poultry Sci., 75: 402 - 406. 
إستجابـة دجـاج إنتاج البيض التجاري للتسكين على كثافات مختلفة و تحت ظروف الإجهاد الحراري. 1_المؤشرات الفسيولوجية والاستجابة المناعية لإنية

حسن بيومي على غريب - محمد عبد الرحمن المناوي - عبد العزيز على عطا الله ـ فريد كمال رمزي إستينو

قسم الإنتاج الحبواني ـكلية الزراعة - جامعة القاهرة - جيزة - مصر

أجريت هذه الدراسة بهدف اختبار النظرية الفرضية بأن إسكان الاجاج البياض على كثاب الإنافات منخفضة

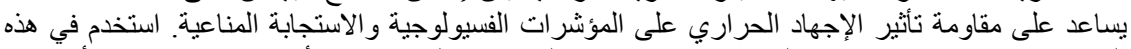

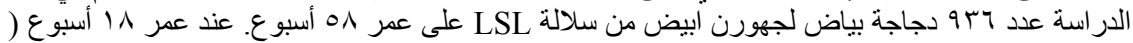

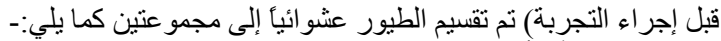

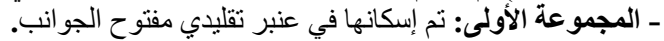

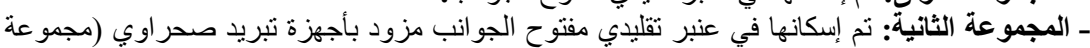
المقارنة).

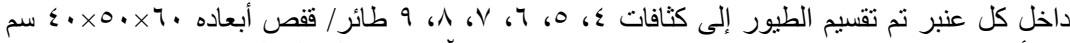

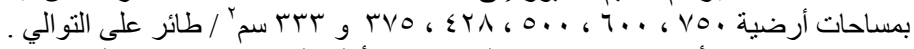

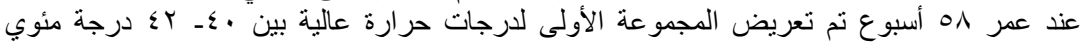

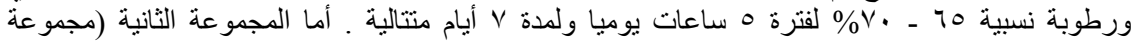

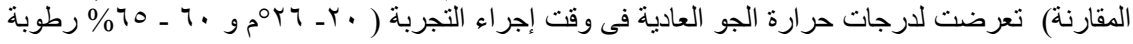

نسبية).

تم تجميع البيانات خلال فترة الإجهاد الحر اري وكانت النتائج كالتالي :

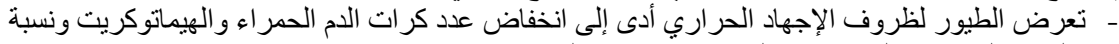

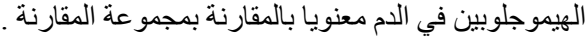

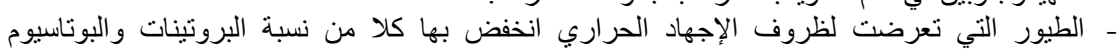

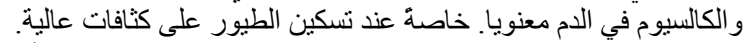

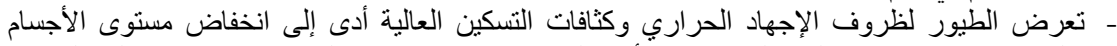

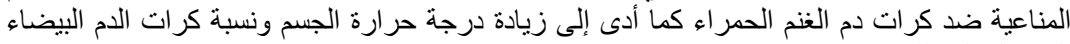

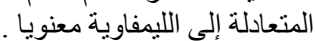

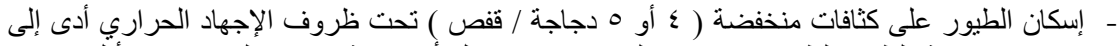

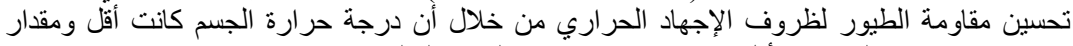

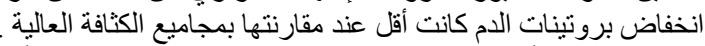

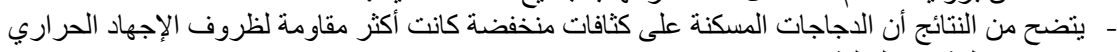

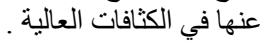

